**Article Accepted, Forthcoming, in Anthropological Quarterly**

\title{
Energy Talk, Temporality, and Belonging in Austerity Greece
}

Daniel M. Knight

\begin{abstract}
Dramatic changes in the energy landscape provide a lens through which to understand local perceptions of temporality, modernity, and belonging in austerity Greece. Re-launched in 2011, the European Union supported solar energy initiative encourages installation of futuristic, high-tech photovoltaic panels on fertile agricultural land. However, winter 2012-13 and 2013-14 witnessed a return enmasse to open-fires and wood-burning stoves as a means for people to heat their homes, something locals associate with material poverty, pre-modernity, and preEuropeanization. Drawing on ethnographic research in the town of Trikala, central Greece, this paper demonstrates how "energy talk" provides a prism through which locals discuss the past, the future, increasing poverty and reassess their belonging in a modern Europe.
\end{abstract}

Keywords: (Energy, Economic Crisis, Temporality, Modernity, Belonging) 


\section{Energy Talk, Temporality, and Belonging in Austerity Greece}

\section{Introduction}

On the sparsely vegetated Plain of Thessaly in central Greece, summer temperatures soar above $40^{\circ} \mathrm{C}$ for weeks on end. Now, in December, the frosty Plain is desolate. In some places, almost all the trees have disappeared. The road to the cemetery in the small village of Livadi, 5 kilometers outside of the town of Trikala where I have conducted ethnographic research since 2003 , is scattered with twigs and small branches - remnants of a recent search for firewood. Just beyond the headstones, glimmering in the winter sun, ten large photovoltaic (solar) panels stand on prime agricultural land. Since the solar program was introduced in 2006 the region has gone photovoltaic-crazy. From home installations to developments on agricultural land and large solar parks producing energy for international export, solar is heralded by the Greek state and European Union as the future for year-round energy self-sufficiency (Knight 2013, Knight and Bell 2013). Yet, as evening draws in on this cold December day, thick smog descends over Trikala as people light their open-fires and wood-burning stoves. While the future-orientated new technology of photovoltaics is advocated by the national government and European Union as a long-term solution to economic sustainability in Greece, winter 2012-13 and 2013-14 have witnessed a return en-masse to wood-burning open-fires (tzakia) and stoves (ksilosompes) last popular during the 1960s and 1970s.

The Greek financial crisis has made global front-page news since 2009, but often the consequences of the economic downturn for peripheral regions are overlooked as 
media outlets adopt an Atheno-centric stance with often cynical analysis based firmly in the field of macroeconomics or mainstream political economy. By employing "energy talk" as a means to gauge how Greeks are dealing with the consequences of severe economic crisis, this article addresses how local people in a town in rural central Greece critique their position in what they term "modern Europe". People re-examine their position vis-à-vis European modernity and the West, and re-evaluate their temporal trajectory towards what they perceive as progress and prosperity. The exploration of these two points emerges from an ethnographic contradiction: the application of photovoltaic panels (a practice associated with European modernity and futuristic technology), and the simultaneous re-introduction of wood-burning stoves (a practice locally associated with pre-modern tradition). Energy talk helps us to understand what has changed and what has remained constant in the Greek response to a crisis widely seen as a new form of colonialism. Through the ethnography presented here it becomes clear that local people perceive energy as critical to understanding broader social and economic phenomena, mirroring the growing opinion among academics that more social science research on energy is urgently needed (Boyer 2014:328). Through energy talk my informants discuss being brought back to dilemmas of identity that they thought they had finally escaped via accession to the European Union and membership of the eurozone. Importantly, here I demonstrate the continued value of pre-crisis ethnography - the work of John Campbell, James Faubion and Michael Herzfeld is particularly pertinent to the present case - to understanding the complexity of currents events in Greece. 
Two seemingly contrasting energy sources - high-tech photovoltaic panels and open wood-burning fires - have become local symbols of the livelihood changes brought about by economic crisis. My research participants associate photovoltaics with clean-green energy, futuristic sustainability, ground-breaking technology, ultramodernity and international political energy consensus. Open-fires conjure images of pre-modern unsustainability, pollution, and extreme poverty'. A fourth-generation agriculturalist with thirty solar panels standing on his once fertile fields, Dimitris laments that every night his village is engulfed in suffocating smog while on the surrounding plains glistening solar panels point to the heavens. Since 2010 Dimitris, married with two young children, has been unable to sell his crops owing to the breakdown of agricultural markets during the crisis - wholesalers have gone bankrupt and consumption is down. He laments that "although we are constantly told by our politicians that we (Greeks) belong to a modern Europe, I can't help thinking that we have gone back in time". Echoing the general feeling among agriculturalists on the plain, Dimitris feels that he has been forced into making a decision to invest in photovoltaics but is not benefiting from the energy harnessed by the panels which is channeled towards urban centers. Instead, he has resorted to illegally felling trees and sourcing unwanted furniture to light his open-fire that keeps his family warm. "You see on the television that people in the larger towns have breathing difficulties, medical emergencies have increased and the fire department is dealing with more house-fires. All this smog must also have environmental consequences. Often the furniture is varnished and the firewood unsuitable". Yet, like in thousands of households nationwide, Dimitris cannot afford 
petrol-powered central heating and states that he has no other option but to light his open-fire despite a desperate plea from the local mayor to "find an alternative".

Energy talk neatly frames the contradiction between the voices in government claiming Greece's rightful place in a modern Europe and Dimitris's feelings of desperation as he struggles to find a way to cope with the devastating crisis. For people like Dimitris, energy has become a discursive framework through which to contemplate wider social, political and economic anxieties and power-struggles - socalled "energopolitics" (Boyer 2014:309-310). The first part of this essay channels local discourse to show how the seemingly contrasting energy solutions have provoked people into thinking about their temporal trajectories; are they part of a prosperous European future or destined to "go back in time" to some archaic premodernity? Drawing on earlier work on the ambiguity of Greece in contemporary geo-politics, the second part outlines how changing energy technologies help us reassess the idea of Greece being caught between East and West, modern and premodern during an era of increasing poverty and suffering.

\section{Temporalities of Energy}

Reshaping the material, spatial, and temporal landscape, shifting patterns in energy production and consumption entail changes "in markets, user practices, policy and cultural meanings" (Geels 2010:495, also Shove 2003, 2009) as both money and land are removed from circulation or used for different purposes (Howe 2014:389). In Trikala the socio-technical changes provoked by economic crisis have resulted in unique localized understandings of history, crisis management, and futures. As he 
sits around his open-fire one December evening, wrapped-up warm in five layers of clothing, Dimitris voices concerns about Greece "going backwards" towards an era when "modernity was a distant dream, people had no home-comforts and we certainly didn't feel European". This feeling is juxtaposed, Dimitris argues, against the insistence of Greek politicians that Greece belongs in the eurozone, European Union and "the same time period as Germany and America". With visible distress and an air of hopelessness, he continues, "people have been complaining that living in Trikala in 2013 is like living in Trikala in 1963, so we were told to look to Europe for the answers, to a future with European Union programs like photovoltaics - look where that has got me ... I now have to wear so many layers (of clothes) so as not to freeze to death!" Dimitris states that the solar panels on his land remind him of an "occupying army colonizing my fields" and his open-fire that "things are only getting worse, we are only going backwards".

A few kilometers away, Sotiris's family has been working the same fields since the agrarian reforms of the early 1900 s. Of leftist disposition, Sotiris is slightly more hopeful that the solar panels are symbols that "Greeks still believe in a more prosperous future". He says that "even the poorest people still believe somewhere in their hearts that Greece is European, modern and will become wealthy again with top technology". But Sotiris's stance must not be confused with blind optimism; rather he is searching for a small glimmer of hope in a nation ravished by fiscal austerity. Sitting around his newly installed open-fire, 73-year-old Sotiris is close to tears, "I have to remain hopeful for my grandchildren's sake. Their future might more realistically be spent huddled around a fire trying to keep warm, a life based in 
the 1960s, in pre-modernity while foreigners exploit our natural resources". Pointing at the roaring fire and pile of logs to the side, he says that his grandchildren's "future is based in the past". "I look at the stove and in the flames I see everything that my family has overcome in the past fifty years. The poverty, the hardship, working our fingers to the bone, and now everything is lost". For Sotiris, open-fires are symbols of historical poverty that is currently being re-lived in crisis-stricken Greece.

Owing to the "sudden and unexpected change" enforced in the form of fiscal crisis (Grosz 1999:28), my research participants feel that their future has become uncertain, highlighted by diverse coping strategies and increased unease surrounding European belonging. Doubts over their temporal trajectory - are they heading forwards or backwards? - and feelings of the past resurfacing in the present are symptomatic of a "scrambling" of temporality (Stewart 2012:191, Knight and Stewart 2016) captured in two alternate energy solutions. Both photovoltaic panels and open-fires represent the haunting presence of painful pasts and uncertain futures. For people in Trikala the prominence of contrasting energy paraphernalia in their daily lives prompts them to rethink their world-view.

Sotiris says that "the paradoxes of current energy technologies" with their intermingling allusions to a high-tech future and a low-tech past make people "reconceptualize their place in space and time ... do we belong to a modern Europe ... are we in the same time as Germany and France?" Pertinent to considering energy infrastructure as a meeting ground of temporalities, Michel Callon (2005) defines sociotechnical arrangements as having the capacity to 'act and to give meaning to 
action'. He says that refiguring these sociotechnical arrangements requires rethinking material, textual and other investments. In this sense, shifts in how people heat their homes in Trikala have awakened dormant feelings and given new meaning to ambiguous notions of belonging - a long-running debate in the anthropology of the region that has acquired new pertinence (see Herzfeld 1987, Faubion 1993, Argyrou 1996, Hirschon 2011).

\section{A Little Ray of Light: the photovoltaic initiative}

The Greek photovoltaic program was first launched in 2006, three years before the nation's fiscal problems made global front-page news. In 2011 the government rebranded the scheme amid considerable fanfare at the prestigious Megaro Mousikis in Athens, citing "the solar economy" (Scheer 2004) as the pathway to repay debt and decrease national deficit (Knight and Bell 2013:4-5). The photovoltaic program ranges from large-scale solar parks producing enough energy for international export (up to 10 gws by 2050 in one park alone), to self-sufficient home installations (up to $10 \mathrm{kw} / \mathrm{h}$ ). Energy export from large developments has been further prioritized since the denouncement of nuclear generation by Germany in 2011, with politicians promising the permanent closure of all German nuclear plants by 2022 . There are also substantial developments on agricultural land where crop production is currently financially unsustainable because of the collapse of markets as a consequence of economic squalor and the uncertain future of the Common Agricultural Policy (CAP). 
A diversification program supported by the European Union, Greek agriculturalists without a market for their crops are encouraged to install photovoltaic panels on their land. The initiative has been met with mixed feelings as the necessity for a stable financial income provided by feed-in tariffs fixed for 25 years is balanced against notions of colonization, occupation and dispossession (Argenti and Knight 2015, Knight and Bell 2013)ii. The rich history of land tenure on the Plain of Thessaly, acute historical consciousness, and issues of national food sufficiency stretching back over 200 years provide the background noise to people's decisions to install solar panels. As such, many locals perceive the solar initiative as a state-sanctioned encroachment on longstanding livelihoods (cf. Richardson and Weszkalnys 2014:5).

The international impact of the Greek initiative is emphasized by the fact that Greece has surpassed its 2020 goal for solar energy production (from 2009 to 2012 annual photovoltaic energy production increased from 53mw to $1018.29 \mathrm{mw}$ ) (Hatziargyriou 2012). German investors have significant interest in large and medium scale photovoltaic developments and have financed parts of the failing major energy company Dimosia Epicheírisi llektrismou (DEI). Notions of colonization are exacerbated as installation companies primarily advertise German products as this rhetoric sells reliability and reassures the consumer of the quality of technology ${ }^{\mathrm{iii}}$.

Agriculturalists now face the daunting prospect that crop production is no longer a viable livelihood strategy beyond subsistence. Farmers are "growing photovoltaics" (fitronoun fotovoltaika) on their land as this is perceived to be the only way to avoid certain historically-based fears of famine (see Herzfeld 1985, Gilsenan 1996:121). In 
the salons of European government, solar energy is heralded as the economic savior of a failing state, viewed as a long-term solution to fiscal austerity, international dependency, and European energy security, and imbues the powers that be with the political authority to oppress and ignore the opinions of local communities.

There is substantial risk involved with placing one's future in photovoltaics, especially on long-term contracts for panels based on agricultural land. As Giannis, 66, explains,

We (famers) have to take a gamble on our future. Our land is lying there idle, it is fertile but we cannot sell our grain. My children and grandchildren have to eat every day. My eldest son has lost his job working in the local government offices and the future of his child, my grandchild, is now uncertain ... If I put photovoltaic panels on my land then the immediate future looks more secure. I mean, I have money in my pocket. My pension has been cut by two-thirds and now the land is all I have. My family fought hard for this land over the past century (until the 1930s it was part of a large landed estate, tsifliki) but now they will go hungry if I don't act. I now say that I "grow photovoltaics". I "grow energy".

Giannis justifies the installation of solar panels by suggesting that moments of the past are returning to haunt local people. As well as references to the long struggle for private property after the annexation of Thessaly to the Greek state in 1881, Giannis emphasizes how close his family is to starvation. He recounts the history of the Great Famine of 1941-43 when 300,000 people died in Athens alone. "We all 
know this. My grandchild knows this. What we are living through fills us with the same pain, the same fear" (see Knight 2012, 2015b). Giannis feels that "Greece has been torn from its path and thrown back in time", saying that he does not trust the politicians and bureaucrats that sell the program, because "they just want to keep us suppressed, to be dominated by their armies ... and for me to return to being a peasant".

Giannis conflates the current economic crisis with moments of the past, primarily the Great Famine. 'The crisis' is at once the tragedies of the 1940s and present-day Troika-occupied ${ }^{\text {iv }}$ Greece and, for Giannis, photovoltaics symbolize the conditions "akin to fifty years ago" when Greece was in a dictatorship and the government threatened to repossess his family's land. His experience of life in Trikala is through vivid local history with unclear future trajectory; it is a boundless "cloud" to which photovoltaics only adds confusion; "they (politicians) should make up their mind. Do we live in the twenty-first or nineteenth century? Am I a modern European or an Ottoman?"

Such confusion is highlighted by Michalis, a 55-year-old father of three who is an ardent supporter of the center-left PASOK party that took Greece into the European Union in 1981. Michalis provides another perspective on the historicity involved in photovoltaic diversification:

I am proud that I have the ability to change my lifestyle towards the future. I would not have chosen to install photovoltaic panels on my home and land, but they are symbols of the future rather than symbols of destitution. I want 
to help my family, and help my nation in this moment of crisis. I am too old to pick up my gun and start a revolution. My father fought during World War Two against occupation, but this time the intelligent thing is a little collaboration. I know what I am doing may seem manipulative, like colluding with the enemy, but nowadays putting food on the table for my family is more important, I cannot let them starve. While everybody else argues about who is to blame for this terrible crisis I have put all my assets into creating some form of future for my family. We were not defeated by Ottoman or German occupation, civil war, or military dictatorship. Photovoltaic panels are a sign of my defiance. I will overcome the economic crisis.

Michalis's narrative resonates with established patterns of "defending the family" identified in Greece by John Campbell. Campbell (1964) distinguishes between the responsibilities of adolescents (pallikaria) and married men. A pallikari must assertively exhibit attitudes of manliness, he must be "prepared to die, if necessary, for the honor of his family or his country" (1964:279). As such, the pallikari is the ideal of manhood. However, after marriage a man must exhibit characteristics of cleverness (eksipnada) and cunning (poniria), demonstrating a quickness of mind and a degree of foresight in protecting his family (Campbell 1964:280-282). Today, these attributes are still legitimate and praiseworthy where the family is the object of protection, even if this means forgoing conscience and pride. Michalis feels that he has shown considerable foresight by investing in photovoltaics, despite historically embedded reservations about "collaboration". "I can only afford to think of 
tomorrow" he tells me. "Once, tomorrow meant the next twenty years; now it literally means the very next day".

Energy is a prominent way that people in Trikala talk about the present crisis in terms of the recurring past and visions for the future. The material presence of photovoltaic panels on their land provokes feelings of being returned to times of foreign occupation, pre-modernity and confusion about what the future holds for the next generation. The solar drive and the return to open-fires are based on conflicting temporal ideals and decisions to install either are informed through a series of "imaginary temporal excursions" both to the past and future (Stewart 2003:483). Discussing the economic situation through energy, people in Trikala see the crisis as polychromic, polytemporal, and polymaterial (Serres 1987, 1995a:60, Bloch 1998:120). To paraphrase Michel Serres (1995a:58), perhaps it is not coincidental that in Greek kairos means both "time" and "weather", signifying the turbulent topological fluctuations in temporal and material flows.

\section{Smoking Hot: a return to wood}

Despite the Plain of Thessaly being awash with solar panels, the energy generated rarely serves the local community. During summer 2012, Antonis, a 40-year-old car mechanic and father of two, commenced construction of an open-fire heating system (tzaki) in his home. The price of petrol required for central heating (kalorifer) was dramatically increasing, there is no mains gas in Trikala, and his business was only bringing in around 30 euros a month, before rent, utility and sustenance payments. Over the course of two months Antonis built the fireplace, ventilation 
system and flue, connected it to the hot water system, and installed a thermostat. He also bought a new handsaw, something he has just used to cut down his neighbor's crab-apple tree for firewood. He narrates, People have cut down so many trees. In some places there is not one left standing. Now they are burning whatever they can lay their hands on plastics, household waste, old chairs, books, and photographs, and we still think of it as ecological ... what else can we do? The cost of petrol for the central heating is far too high and nobody is making any money at work ... At night you cannot breathe in Trikala, the air is so thick with smoke from the fires. You cannot see the end of our street.

Although Antonis's business is all but bankrupt, his mother continues to support him, his wife, 5-year-old daughter, and 3-year-old son through her severely reduced pension and a lifetime of savings. In the current economic climate of soaring unemployment and constant tax increases, livelihood diversification is both commonplace and necessary (Knight 2015c). Antonis has created a side-line selling and installing motors for wood-burning heating systems which he stores in his garage alongside exhaust systems and turbo chargers ${ }^{v}$.

There are now more than 30 shops in Trikala (population 51,862 ) selling all forms of wood-burners. You can buy wood or pellets from any one of the street newsstands (periptera). The trouble is that this business initiative is no longer innovative. Everyone has the same idea, but the prices remain very high. The demand is also very high, but the market is swamped. People have begun buying all forms of fire systems, from cheap free-standing stoves to 
whole industrial-scale systems. All the trees on public land, the private allotments, even in the children's playground, have been cut down. At weekends you see cars and pick-up trucks stacked full of firewood. Some people have been stopped by police, fined, and forced to empty their spoils by the side of the road.

In December 2012, a local news bulletin reported that research conducted by the University of Thessaly revealed that air pollution levels in some parts of the region are 30 to 40 times the recommended limit. Local politicians in Volos and Karditsa appealed to the conscience of all citizens not to use unregulated sompes and tzakia. The bulletin was followed by an advertisement: "buy a woman's watch and get a free wood-burner (ksilosompa)".

During winter 2013-14 my landlady, Giota, a retired 68-year-old widow, would spend each evening sat next to her open-fire, installed by Antonis over the previous summer. Giota has lived through many social crises in her time and believes that the "return to the past" is captured through the installation of open-fires. She also raises questions about how time and modernity do not equate to knowledge. "Knowledge has been lost because we thought we were modern" she says, Now people are just burning anything and it is so dangerous. People are choking on the thick air - my daughter has asthma and has recently experienced serious problems breathing ... Back when I was a child we all used to have wood-burning fires, the whole village, but we knew what to 
burn and there wasn't the same feeling of desperation. But we thought this time had passed, we are Europeans now.

Repeating a line regularly heard among retirees in Trikala, Giota feels that open-fires are symbols of the past and of poverty, "unless you are a very rich person from Athens who thinks it is fashionable". She recounts a report aired on national television the week before that compared what was happening in Athens in 2013 to the pollution in London during the industrial revolution. "In London" she says "transport was stopped for two days as people could only see two meters through the smoke". Discussing current problems heating her home with a group of fellow retirees in a local coffee shop, the ladies agree that they have been "forced back in time to another era of Greece, an era before the dictatorship (1967-1974) when Greece was cut off from the world". This event is often referred to in quotidian discourse as the boundary between pre-modern, pre-European, "poor" Greece and modernity, Europeanization, westernization and prosperity (Greece joined the European Community in 1981). Giota and her friends say that although Greece is now supposedly in "Europe", it cannot be denied that they are now in freefall "back through the decades". She claims that she is freezing to death in her home while her government pumps billions into an energy program that is designed to line the pockets of multinational corporations and foreign politicians, highlighting the complex power games played over energy (Boyer 2011, 2014). With a smirk, she declares that, of course, "there is no smoke without fire!" 
Firewood is now imported to Trikala from as far away as Bulgaria and the Former Yugoslav Republic of Macedonia where it is purchased in bulk at low prices by opportunistic entrepreneurs to be sold for up to 500 percent profit south of the border. Illegally felled wood is also transported in articulated lorries from the forests around Metsovo, Epirus, just over the regional border, and sold for 180 euros per tonne in western Thessaly. Clandestine deliveries of illegally sourced wood regularly take place in the dead of night by men in convoys of blacked-out pick-up trucks. Torrential winter downpours coupled with an increase in illegal logging have recently caused substantial flooding and landslides in Thessaly and Epirus as a result of deforestation. Wood-burners are also imported across the Balkan borders to be sold in showrooms in central Greece.

Antonis, the mechanic from the above narrative, has decided to buy, sell, and install motors for open-fire ventilation systems and provides a commentary on the new business opportunities.

We are trying to get by as best we can, to put our skills to use. I had installed a ksilosompa in the workshop many years ago and now I have built a tzaki in our house. If I can do it for myself, I can do it for other people too. It is better than sitting around doing crosswords all day.

In summer 2012 Antonis was considering working on photovoltaic installations as a side-line to his mechanics business. He says that solar panels are easy to install but it would have been strange working on "such a futuristic program". He decided against 
this option as the labor market had become swamped with mechanics diversifying to work, unofficially, on photovoltaic developments. Antonis continues, Energy is something that everybody needs in order to live, to survive, that is why all the new taxes introduced as part of the Troika bailout conditions get added to our DEI electricity bill - because if you don't pay the bill you won't have electricity. If you live in an apartment block and one tenant doesn't pay their contribution to the energy bill then the whole block gets cut off. You get thrown back into the Dark Ages! I just try to pick up what work I can and energy is a big problem that needs resolving. And all this when we don't even know if tomorrow there will still be a Greek state, a European Union or another civil war!

\section{Modernity: Best Foot (Backward and) Forward}

The two forms of energy practice currently co-existing in Trikala have reignited debate concerning Greek geographical, political and ideological belonging that has a considerable academic lineage. On the fringes of Europe, scholars of Greece have regularly interrogated the nation's place between Orient and Occident, East and West, Western Europe and the Balkans, and Modern and Ancient (for instance, Demetracopoulou-Lee 1953, Herzfeld 1987, Faubion 1993, Argyrou 1996, Hirschon 2010 $)^{\text {vi }}$. The diverse forms of temporality involved with the two energy solutions triggers imaginations of modernity and belonging discussed locally and nationally since World War Two. 
In Greece, modernization (eksygxronismos) encompasses understandings of economic as well as social advancement and stands for the historical and cultural commitment of the Greek people to the West (Clogg 1992:179, 181, Theodossopoulos and Kirtsoglou 2010). Political rhetoric over the past thirty years has revolved around two ambiguous poles - Greeks as the ancestors of modern Europe, and Greeks residing on the margins of the continent, partially leaning towards the Balkans and the East. Modernity plays a central role in the struggle for identity and power for local people feeling caught between Occident and Orient, 'the West' and 'the Other'. Arguing for the plurality of modernity, Faubion (1993:133) notes that "the two great occidental catalysts of governmentalism - the Protestant routinization of personal conduct and the industrial automation of production - have had ... relatively little impact on Greece" meaning that Greek modernity has been formed on a path somewhere between occident and orient. With Troika-enforced austerity, failing European fiscal unity and increasing social poverty, questions of European belonging and modernity have never been more poignant for my research participants who choose to discuss their opinions through energy talk.

Greece has been repeatedly hailed as the birthplace of civilization and the 'living ancestor' of all contemporary European nation-states, while being bombarded with political and geographical questions concerning 'cultural belonging'vii . The Ottoman Empire was considered by Renaissance Europe as the "embodiment of barbarism and evil", thus historically and culturally speaking, Greece is symbolically both holy and polluted (Herzfeld 1987:7). As Herzfeld (1987:2) once argued “Modern Greece does not fit comfortably into the duality of Europeans and Others, especially as 
Greeks are themselves ambivalent about the extent to which they are European". When I first went to the field in 2003, this ambivalence toward Europe seemed to have been overcome through nearly thirty years of economic prosperity and European integration ${ }^{\text {viii }}$, yet the current crisis has reopened the debate at a grassroots level.

The economic crisis and return to poverty for many citizens has led to media speculation over Greek commitment to "Europe". In terms of energy, one foot is now striding confidently towards the rapidly expanding future of technology and sustainability, while the other is staggering back towards energy consumption that locals term "archaic" and associate with poverty and pre-Europeanization. This duality is emphasized by changes in other livelihood practices, such as the increasing amount of people growing their own fruit and vegetables on small plots of land for greater self-sufficiency, triggering reflection on images of European "resemblance and difference" (Theodossopoulos 2006:6).

A 68-year-old retired school teacher, Dorothea, reflects on the years of financial prosperity by stating "that is another lifetime. Those days before the crisis seem so distant now ... I live in a different body, see the world through different eyes ... every day I physically retch and my stomach pains from the crisis." Dorothea breaks down in tears as she recalls how her pension has been cut by two-thirds, she has no money for petrol central heating and she has been forced to put her second home in her ancestral village up for sale. "How do they expect us to survive?" she asks. She claims that "the foreigners have taken our lives, taken our food, and have forced us back in 
time. We thought we were European but they are treating us worse than dogs" (see Knight 2015a:2).

When talking about her newly installed open-fire system, Dorothea contrasts her notions of European belonging with the alternative of being "part of the Balkans", the former associated with wealth and modernity, the latter with extreme poverty and civil conflict. In the 1930s, Dorothea's father travelled throughout northern Greece, southern Albania and Bulgaria working as a stonemason before migrating with his family from his village in the mountains of Greek Macedonia to Trikala during the civil war (1946-49), an event that scattered the extended family across the Balkans. Dorothea's parents decided to move to Trikala, some 120 kilometers away, when the fighting between communist guerillas and groups loyal to the nationalist army became too fierce. But because of divided allegiances, Dorothea's family split; while her parents headed to Trikala on the central plains, her uncle's family left for Bulgaria. Her uncle changed his family surname and settled near the capital city, Sofia.

Dorothea's family story is by no means unique. She was part of a wave of migrants that left their mountain villages during the civil war to set up home across northern Greece or relocate further afield to Bulgaria, Macedonia (FYROM) and Romania. Since the outbreak of the economic crisis Dorothea believes that Greece has become "like the Balkans", saying that she feels she has "slipped back in time" to an era of "pre-modernity, pre-Europeanization". Gesticulating towards her open-fire, she expresses deep concern that her grandchildren will be brought up in a nation that 
can now "seriously be compared to Bulgaria rather than the West; our future belongs to the Balkans". Dorothea feels frustrated with the broken promises of wealth and modernity made by the European Union and Greek politicians throughout the 1980 s and 90 s, something she says is captured in the need to burn wood to keep warm, noting that both her family and her nation chose a particular historical trajectory when they committed to Europe rather than the East or the Balkans. $^{\text {ix }}$

The so-called era of Greek "Europeanization" in the 1980s challenged long-existing political, economic and ideological structures (Hirschon 2008, 2010:289) ${ }^{x}$. Furthermore, Greeks expected economic and political security from European Community and eurozone membership, banishing notions of an ambivalent European identity and laying to rest geographical, historical, religious, and political ambiguity. The promise of modernization, contemporaneity, and a stable future trajectory was seemingly delivered during thirty years of nigh-uninterrupted prosperity. Far from being caught between familiar and unfamiliar, belonging and exclusion, political and fiscal unity with Europe was seen as ensuring socioeconomic prosperity for Greece through European solidarity (Pryce 2012). Changing livelihood strategies during the crisis, including the mass return to wood-fuelled heating, has made people reassess their relationship to Europe and associated notions of modernity and prosperity. In Trikala, people once again feel trapped between past and future as Herzfeld once suggested, imprisoned by contrasting images of Europe - the giver and the taker-away. This is dramatically reinforced through the visual 
images of gigantic photovoltaic panels funded by a European Union program, and towering piles of firewood, a symbol of European-enforced austerity. ${ }^{\mathrm{xi}}$

Contrasting artifacts - solar panels and open-fires - are time capsules with the ability to transport actors on different trajectories. It is around these material objects that multifaceted "indigenous historicization" is centered (Stewart 2012:190). Ioanna, a public sector employee aged 50 with a tendency for political conservatism, has installed photovoltaic panels on her home and farmland on the outskirts of Trikala:

The photovoltaic program promises a stable income, something which is difficult to find nowadays. With the support of the European Union there is more chance that the contracts will be fulfilled and less money will be lost to the corrupt hands of politicians along the way ... When Andreas Papandreou took us into Europe in the 1980s many things were lost from our culture. It became all about money, showing that you had money and buying as much status as possible. Everybody that wanted a job got a job and loans were so easy to come by. But without realizing it we were loaning money from the next generation. The next generation will have to pay for the national craze in everything "European" and "modern".

Ioanna believes that nobody in Trikala truly understood international capitalism and the power games played by other European governments. She says that her children's future has been lost to the hollow promises of modernity and capitalism, stating that she is heartbroken that "we sacrificed our grandchildren's future for the sake of modernity and technology, in the name of Europe". Like many people from 
across the political spectrum, loanna remembers how "everyone loved the Greeks as the ancestors of the Ancients, that land of sun and hospitality (filoxenia)". Although acknowledging that Greece benefitted from tourism and European Union agricultural initiatives, she echoes the general feeling that Greece has now been tossed aside by European partners, punished by the same people who promoted modernity.

For thirty years we had freedom, we could have whatever we wanted, but Europe has also provided us with unrealistic expectations that we can no longer satisfy. This crisis is a reality check ... unregulated modernization has come at a price. Some things that Europe offer still have worth - the majority of people, including myself, want to remain part of the eurozone and the European Union. Greece is part of the European continent after all so how can we say that we are not part of Europe ...

Discussing the photovoltaic program as illustrative of European promises of modernity shrouded in secrecy and ulterior motives, loanna describes the initiative as "a Trojan horse" and "a gift that is used to keep us happy but all is not what it seems". She emphasizes how difficult it will be for people to accept that living in Greece in 2015 will feel the same as Greece during the 1960s and 1970s.

Some people say that another military junta is precisely what is required to solve this crisis, but they are not looking at the bigger picture. Think of where we were thirty to forty years ago and where we are now. We cannot write all that off immediately, but we must adapt our style of living for the current situation ... we have survived much worse in the past. 
She suggests that at the moment a combination of European-backed energy technology (photovoltaics) and "old" ways of coping (saving money through woodburners) is the best way of dealing with a desperate situation.

\section{Back to Balkan, or Botswana?}

The quote below from Herzfeld, writing in 1987, perhaps surprisingly captures the sentiment of many Greeks in 2015.

"The Greeks of today, heirs - so they are repeatedly informed - to the glories of the European past, seriously and frequently ask themselves if perhaps they now belong politically, economically, and culturally to the Third World. Whether as the land of revered but long dead ancestors, or as the intrusive and rather tawdry fragment of the mysterious East, Greece might seem condemned to a peripheral role in the modern age" (Herzfeld 1987:3).

At the turn of the millennium Herzfeld's perceptions of ambivalence towards Europeanization would have seemed unconvincing to a social researcher visiting Greece. Futuristic technologies, such as the internet, European Union supported infrastructure schemes, European fiscal unity, and the impending Athens Olympic Games were opening up even the remotest areas to everything the West had to offer. Although since 2009 Greece has certainly not been on the periphery of European political and economic speculation, the question of belonging to the "First" or "Third" world has resurfaced on local and national stages as people rhetorically pose the questions "Who are we?" "What have we become?" "Where are we now ... 
when are we now?" The current energy landscape is an example of how the experience of time and belonging splits into two heterogeneous dissymmetrical emissions, one toward the future and another toward the past, coexisting wholly within the present (Turetzky 1998:217). This leads to multi-layered perspectives of crisis and the fragmentation of temporal experience as people attempt "to situate themselves within a trajectory" (Kirtsoglou 2010:2).

Stavros, 23 , is a livestock owner from the Pindos Mountains, who resides in Trikala. In 1997 his mother installed photovoltaic panels on their home and a small portion of their 1,500 stemmata (375 acres) rented land. He claims this was one of the first high-tech solar installations in central Greece. Two years later his mother took a loan to place small wind turbines on another plot of land to provide nearly 100 percent energy self-sufficiency. This was made possible by extensive research into, and participation in, European Union agricultural and entrepreneurial business schemes. Some of the investment did not prove beneficial as program payments did not materialize or were substantially curtailed, and at times the bureaucracy was impenetrable. Since 2004, as well as tending to his sheep, goats, and cattle, Stavros has sold wood felled from the forest on his land at 130 euros per tonne. Twothousand-and-twelve was the first year he made a significant profit from this activity and he has since commenced a lucrative trade in illegal logging with three friends, delivering logs felled from mountainsides to customers between 1am and 4am. He says that most people have no real understanding of planning for the future. They are "happy with what they have got here and now, and cannot be bothered to investigate initiatives for sustainable improvement". Although Stavros does not have 
a license to fell, transport and sell the firewood, he is saving up for two second-hand lorries to assist with this business venture. He is a man built on investing in European initiatives and now he is one of the few people making profits during the crisis.

Residing in the same neighborhood of Trikala as Stavros, Vassilis is 44-years-old and has recently lost his job working for a telecommunications company. With two young children and an unemployed wife, Vassilis's family live on a small amount of money provided by his mother's reduced pension. Educated at a Romanian university in the mid-1990s, Vassilis says that he has witnessed first-hand the positives and negatives of life in other parts of the Balkans. I have known Vassilis for nearly a decade and he regularly recites stories of his life in Romania over a shot of tsipouro or a cup of coffee. Many of his stories revolve around the poverty he encountered when living abroad and the relief he felt when returning to "civilization" in Greece, as well as the unprecedented levels of corruption engrained in everyday life in Romania - somewhat ironic given the well documented attention given by Troika to tackling so-called endemic corruption in Greece.

Vassilis says that during the 1990s there was a cavernous distance between Greece and the rest of the Balkans in public imagination. He talks of Greece as a prosperous, wealthy and democratic nation, stable within the European Union and international markets, where citizens were sure about their prosperous futures. Romania and the wider Balkans were, for people like Vassilis, the abject opposite, struggling to find their feet after the fall of communism, offering their citizens a less than certain vision of the future. Like many inhabitants of Trikala, over the next ten years 
Vassilis's excursions into other Balkan nations comprised of short trips across the border to Bulgaria to stock-up on cheap food and alcohol or fill-up large canisters of petrol. But things changed for Vassilis in 2014 when he headed back to Bulgaria in a privately hired lorry to purchase firewood for his newly installed wood-burning stove. That trip to Bulgaria in 2014 really got Vassilis thinking, for he was going over the border to buy cheap firewood because he had been forced by the economic crisis - forced by northern European bureaucrats and his own government - to stop using his more expensive petrol-fuelled central heating, which he could no longer afford. He had to heat his home with firewood, generally perceived as an "archaic method". "I was going backwards", he states, "Greece was going backwards into the past".

Although Greek politicians and the mass media regularly emphasize Greece's important role in the modern European political project, Vassilis can't help thinking that soon "Greece will become just another Balkan nation". Noting that Greece ranked below Botswana in recent press-freedom and corruption indices and that only African nations usually miss IMF payments, he continues,

When I studied in Romania modernity was a distant dream, local people had no home-comforts and they certainly didn't feel European. They had many dreams but were caught between their past and their future. Now Greeks are feeling similar ambiguous emotions about where they truly belong ... It cannot be denied that we are now in free-fall back through the decades. I know that when I am freezing to death in my home, queuing at empty ATMs or reading about food banks in the urban centers. 
Stoking Vassilis's feelings of ambiguity and confusion, the ongoing discussion about Greece's membership in the European single currency and the so-called "Grexit" alternative that would signal a return to the Drachma have been overtly framed in the Greek mass media as a choice between Europe and the Balkans, West and East, Occident and Orient, the modern and the archaic. Thus, understanding localized concepts of temporality, history and belonging is paramount in order to move away from an analysis of the Greek crisis based on generalized political economy and media hysteria. Changes in energy practice - what Vassilis terms "a snapshot of alternative futures" - are lenses through which people reconsider their position in the modern European political landscape.

\section{Conclusions}

The focus on how people talk about the new solar program and the return to wood heating in terms of modernity and belonging offers a unique perspective on life in crisis-stricken Greece. As socioeconomic circumstances radically change raw materials have shifted functionality, realigning local livelihoods. Natural resources have always been economic assets, but now they are harnessed in alternative manners. Trees are cut down and used for firewood, agricultural land is transformed to host photovoltaic panels, and the sun's energy is channeled for power rather than food production. For locals, transformations in the energy landscape facilitate a much broader discussion of the current crisis through issues that have long haunted the Greek imagination - modernity, Europeanization and belonging. Energy provides 
the focus for exploring these existential dilemmas of a people facing doomsday, themes familiar to the anthropology of Greece.

Energy talk is a method through which people rethink their temporal trajectory towards a past of extreme hardship and a future of broken promises, of belonging to a modern Europe on the one hand or a Balkan or "third world" region stereotyped as war-torn and impoverished on the other. They face a "decision moment" provoked by crisis (Knight and Stewart 2016:11) whether to go along with the photovoltaic "occupation" of their land that has done nothing to lessen their dependence on polluting natural fuels such as wood or to slow the pace of deforestation and illegal trading that this dependence has generated.

Questions remain as to the sustainability of the new energy landscape. The over-use of agricultural land for solar energy production problematizes the future of national food security, and increased deforestation has already had severe environmental impacts. Futuristic photovoltaic technology cuts across existing networks of knowledge and practice, challenging preconceptions of livelihood strategies and economic activity (Strathern 1996). Solar energy offers a new opportunity, but on different social, historical, and material terms. The return to wood-burning energy signifies a challenge to notions of European belonging, modernization, progress, and future economic prosperity, being symbolic of wider questions concerning the price of European integration over the course of thirty years. Despite significant problems of air pollution and landslides, wood continues to be wrongly assumed as a 'green sustainable' alternative to expensive petrol heating. 
The current energy landscape is full of paradoxical images. Investing in forwardlooking high-tech energy generation or 'archaic' wood-burning is perceived as a choice between two short-term solutions. The combination of conflicting coping strategies should not be surprising as people prioritize immediate survival over nagging environmental concerns and fears of being 'colonized' by foreign energy companies. Thirty years of general socio-economic prosperity have been abruptly ruptured, ejecting people back into an ambivalent confused state of belonging described by Herzfeld in the mid-1980s. Photovoltaic panels and open-fires are characteristic of different understandings of trajectory and belonging, incorporating past futures that shape the rhythm and orientation of temporalities. Energy is an important lens through which people can locate themselves within the social chaos that is austerity Greece. A focus on energy goes some way to highlight the complex understandings of the current crisis that is too often glossed as a matter of macroeconomics or mainstream political economy.

\section{References}

Argenti, Nicolas and Daniel M. Knight. 2015. Sun, Wind and the Rebirth of Extractive Economies: Renewable energy investment and metanarratives of the crisis in Greece. Journal of the Royal Anthropological Institute, Volume 21, Issue 4, pp: 781802.

Argyrou, Vassos. 1996. Tradition and Modernity in the Mediterranean: the wedding as symbolic struggle. Cambridge: Cambridge University Press. 
Bloch, Maurice. 1998. How We Think They Think: anthropological approaches to cognition, memory and literacy. Boulder: Westview Press.

Boyer, Dominic. 2011. Energopolitics and the Anthropology of Energy. Anthropology Newsletter, May, 5, 7.

Boyer, Dominic. 2014. Energopower: An introduction. Anthropological Quarterly, Volume 87, Number 2, pp:309-334.

Bryant, Rebecca. 2014. History's Remainders: On Time and Objects after Conflict in Cyprus. American Ethnologist, Volume 41, Number 4, pp: 681-697.

Callon, Michel. 2005. Why virtualism paves the way to political impotence. European Electronic Economic Sociology Newsletter, Volume 6, Number 2.

Campbell, John. 1964. Honour, Family and Patronage: A Study of Institutions and Moral Values in a Greek Mountain Community. Oxford: Oxford University Press.

Clogg, Richard. 1992. A Concise History of Greece. Cambridge: Cambridge University Press. 
Demetracopoulou-Lee, Dorothy. 1953. Greece: Cultural Patterns and Technical Change. In Mead, Margaret. (ed.). Cultural Patterns and Technical Change: a manual prepared by the World Federation for Mental Health. Paris: UNESCO.

Faubion, James. D. 1993. Modern Greek Lessons: a primer in historical constructivism. Princeton: Princeton University Press.

Fontefrancesco, Michele. F. 2012. Crafting the Local: Gls, jewellery, and transformations in Valenza, Italy. Social Analysis, Volume 56, Number 3, pp: 89-107.

Geels, Frank. W. 2010. Ontologies, socio-technical transitions (to sustainability), and the multi-level perspective. Research Policy Volume 39, pp: 495-510.

Gilsenan, Michael. 1996. Lords of the Lebanese Marches: violence and narrative in an Arab society. London: I.B. Tauris.

Grosz, Elizabeth. 1999. Becomings: Explorations in Time, Memory, and Futures. London: Cornell University Press.

Hatziargyriou, Nikolaos. 2012. The State of Photovoltaic Energy Generation in Greece. PowerPoint Presentation, accessed 30 ${ }^{\text {th }}$ January 2013.

Herzfeld, Michael. 1985. The Poetics of Manhood: Contest and Identity in a Cretan Mountain Village. Princeton: Princeton University Press. 
Herzfeld, Michael. 1987. Anthropology through the Looking-glass: critical ethnography in the margins of Europe. Cambridge: Cambridge University Press.

Herzfeld, Michael. 2005. Cultural Intimacy: social poetics in the nation-state (Second Edition). London: Routledge.

Hirschon, Renée. 2008. Presents, Promises and Punctuality: accountability and obligation in Greek social life. In Mazower, M. (ed.). Networks of Power in Modern Greece: essays in honour of John Campbell. London: Hurst.

Hirschon, Renée. 2010. Person and Nation: Church, Christian Community, and Spectres of the Secular. In Hann, C. and H. Goltz (eds.). Eastern Christianities in Anthropological Perspective. Berkeley: University of California Press.

Hirschon, Renée. 2011. Cultural Mismatches: Greek Concepts of Time, Personal Identity, and Authority in the Context of Europe. Oxford College of Marketing Working Paper. Also in Featherstone, K. (ed.). 2013. Europe in Modern Greek History. London: Hurst.

Howe, Cymene. 2014. Anthropocenic Ecoauthority: The winds of Oaxaca. Anthropological Quarterly, Volume 87, Number 2, pp: 381-404. 
Kalyvas, Stathis. 2015. Modern Greece: What Everyone Needs to Know. Oxford:

Oxford University Press.

Kirtsoglou, Elisabeth. 2010. Introduction: Rhetoric and the Workings of Power - the Social Contract in Crisis. Social Analysis, Volume 54, Issue 1, pp: 1-14.

Knight, Daniel. M. 2012. Cultural Proximity: Crisis, Time and Social Memory in Central Greece. History and Anthropology, Volume 23, Issue 3, pp: 349-374.

Knight, Daniel. M. 2013. Famine, Suicide and Photovoltaics to Famine: Narratives of the Greek Crisis. GreeSE Working Paper Series, Hellenic Observatory, London School of Economics and Political Science, No. 67, pp: 1-44.

Knight, Daniel. M. 2015a. History, Time, and Economic Crisis in Central Greece. New York: Palgrave Macmillan.

Knight, Daniel. M. 2015b. Wit and Greece's economic crisis: Ironic slogans, food, and antiausterity sentiments. American Ethnologist, Volume 42, Number 2, pp: 230-246.

Knight, Daniel. M. 2015c. Opportunism and Diversification: Entrepreneurship and Livelihood Strategies in Uncertain Times. Ethnos: Journal of Anthropology, Volume 80, Number 1, pp: 117-144. 
Knight, Daniel M. and Sandra Bell. 2013. Pandora's Box: Photovoltaic Energy and Economic Crisis in Greece. American Institute of Physics Journal of Renewable and Sustainable Energy, Number 5, pp: 1-16.

Knight, Daniel M. and Charles Stewart. 2016. Ethnographies of Austerity: Temporality, Crisis and Affect in Southern Europe. History and Anthropology, Volume 27, Number 1, pp: 1-18.

Malaby, Thomas. 2003. The Currency of Proof: Euro competence and the refiguring of value in Greece. Social Analysis, Volume 47, Number 1, pp: 42-52.

Mitchell, Jon. 2002. Ambivalent Europeans: ritual, memory and the public sphere in Malta. London: Routledge.

Pryce, Vicky. 2012. Greekonomics: the euro crisis and why politicians don't get it. London: Biteback Publishing.

Richardson, Tanya and Gisa Weszkalnys. 2014. Introduction: Resource materialities. Anthropological Quarterly, Volume 87, Number 1, pp: 5-30.

Scheer, Hermann. 2004. The Solar Economy: Renewable energy for a sustainable global future. London: Earthscan. 
Serres, Michel. 1987. Statues. Paris: François Bourin.

Serres, Michel. (with Latour, Bruno). 1995a. Conversations on Science, Culture, and Time. Arbor: University of Michigan Press.

Serres, Michel. 1995b. Genesis. Ann Arbor: University of Michigan Press.

Shove, Elizabeth. 2003. Converging Conventions of Comfort, Cleanliness and Convenience. Journal of Consumer Policy, Volume 26, pp: 395-418.

Shove, Elizabeth. 2009. (ed.). Time, Consumption and Everyday Life: practice, materiality and culture. Oxford: Berg.

Stewart, Charles. 2003. Dreams of Treasure: Temporality, Historicisation, and the Unconscious. Anthropological Theory, Volume 3, Number 4, pp: 481-500.

Stewart, Charles. 2012. Dreaming and Historical Consciousness in Island Greece. Harvard: Harvard University Press.

Strathern, Marilyn. 1996. Cutting the Network. The Journal of the Royal Anthropological Institute, Volume 2, Number 3, pp: 517-535.

Theodossopoulos, Dimitrios. 2006. Introduction: The 'Turks' in the Imagination of the 'Greeks'. South European Society and Politics, Volume 11, Number 1, pp: 1-32. 
Theodossopoulos, Dimitrios. 2013. Infuriated with the Infuriated? Blaming tactics and discontent about the Greek financial crisis. Current Anthropology, Volume 54, Number 2, pp: 200-221.

Theodossopoulos, Dimitrios. 2014. The Ambivalence of Anti-Austerity Indignation in Greece: Resistance, Hegemony and Complicity, Volume 25, Number 4, pp: 488-506.

Theodossopoulos, Dimitrios. and Elisabeth Kirtsoglou. (eds.). 2010. United in Discontent: local responses to cosmopolitanism and globalization. Oxford: Berghahn Books.

Turetzky, Philip. 1998. Time. London: Routledge.

\footnotetext{
'People acknowledge the irony that for the past twenty years open-fires have represented middle class urban opulence as much as 'village life'. However, since the onset of economic crisis this symbolism has shifted and today wood-burning is understood as a mark of austerity. It is also interesting to note that both photovoltaics and tzakia are reincarnations of previous technologies - the solar heater introduced to Greece in the 1980s and the open-fire synonymous with village life throughout the mid-twentieth century.

ii In her analysis of the development of large-scale wind parks across the Isthmus of Tehuantepec in Oaxaca, Mexico, Cymene Howe notes that local people do not stand to benefit from the energy produced on their land and yet face all the risks and costs
} 
associated with its production, she describes the disenfranchisement of local populations in the name of green development as typified by an 'extractive ethos' (2014:388).

iii Low-cost Chinese panels are regularly installed without the knowledge of the consumer in order to provide further maintenance work in forthcoming years. Michele Fontefrancesco (2012:89) argues that there is an inherent link between the nation where an object is manufactured and notions of quality and locality.

${ }^{\text {iv }}$ Troika is the name given in Greece to the European Commission, European Central Bank and International Monetary Fund that administer the bailout plan.

${ }^{v}$ The increasing use of tzakia and ksilosompes is by no means restricted to the Greek periphery. One of the worst affected areas is Athens where pollution levels skyrocketed in winter 2012-2013 and 2013-2014. There has been mounting pressure on the Greek government to implement strict regulations on the use of open-fires, as well as calls to return petrol prices to their 2010 levels to discourage the installation of wood-burners. Politicians are also threatening to impose extra tax on people who have installed wood-burners in their homes.

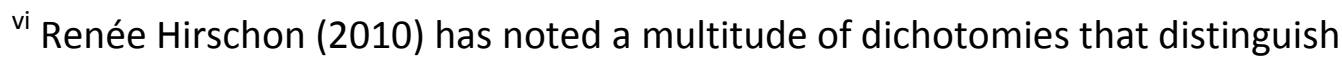
modern Greek society from other 'Western' contexts. She specifically highlights the overlap between national and religious identity and secular and religious domains, remnants of Greece's historical trajectory from the Ottoman Empire (2010:295, 298, see also Theodossopoulos 2013:217, 2014).

vii Jon Mitchell (2002) discusses the case of Maltese European belonging and ambivalent cultural identification with 'the West'. 
viii For a discussion of Greek entry into the eurozone see Thomas Malaby (2003)

${ }^{\text {ix }}$ As Stathis Kalyvas (2015:2) has recently argued, Greece has launched a series of ambitious projects of state building, democratization, and economic development in a quest to achieve modernity, many of which have ended in epic disaster. Yet Greece remains one of the most prosperous nations in the Balkan region and has gained entrance to exclusive European political and economic clubs.

${ }^{\mathrm{x}}$ Faubion argues that marginal industrialism in urban centers such as Athens suggests that modernity in Greece is political not economic (1993: 9-10, 122). However, he goes on, even the Greek political sphere is still noticeably 'elsewhere' rather than 'of the occident' (Faubion 1993:122, 133, 137).

${ }^{x i}$ In her discussion of the polychronicity and multitemporality of objects in neighboring Cyprus, Rebecca Bryant argues that objects "play a role in mediating history and memory because of the ways in which they aid us in reorienting the relationship of past, present, and future". Objects contain "a temporal dynamism capable of exploding, imploding, twisting or braiding the past" (Bryant 2014, also Stewart 2012). 